\title{
Mathematical Connection Analysis of High School Students with Accommodator and Diverger Learning Style
}

\author{
Kusnul Itasari ${ }^{1 *}$ Ikrar Pramudya $^{2}$ Isnandar Slamet $^{3}$ \\ ${ }^{1}$ Postgraduate of Mathematics Education, Faculty of Teacher Training and Education, Universitas Sebelas \\ Maret, Surakarta, Indonesia \\ ${ }^{2}$ Department of Mathematics Education, Universitas Sebelas Maret, Surakarta, Indonesia \\ ${ }^{3}$ Department of Mathematics and Natural Sciences, Universitas Sebelas Maret, Surakarta, Indonesia \\ *Corresponding author. Email: khusnul.itasari17@gmail.com
}

\begin{abstract}
The objectives of this paper is to look at how high school students with accommodator and diverger learning styles solve math problems. This type of research is exploratory descriptive research. The research subjects were students of SMA N Kebakkramat with accommodator and diverger learning styles. Data collection methods using questionaries, tests, and interviews. Sampling was done by snowball sampling. The technique of analysis was using triangulation techniques. Indicators of mathematical connection include: (1) Applying mathematical concepts from other mathematical topics to solve problems, (2) Applying mathematical concepts in trigonometry material to solve problems correctly, (3) representing the relationship of concepts and procedures, (4) applying mathematical concepts on questions related to everyday life, (5) Using mathematical concepts on questions related to other subjects. The results showed that students with the accommodator learning style were able to fulfill all indicators of mathematical connection. Meanwhile, students with divergent learning styles are not able to fulfill the second connection indicator.
\end{abstract}

\section{Keywords: Accommodator, Connection, David kolb's, Diverger.}

\section{INTRODUCTION}

Student education consists of stages that must be passed by all students. From Kindergarten to High School (SMA), students are familiar with arithmetic. Arithmetic has an important role in everyday life, besides that mathematics is also considered as the premise of other fields of science [1]. The idea of mathematics as an organized and systematic science shows that ideas andstandards in mathematics are interrelated with each other [2] . Arithmetic can see andconnect various points that influence each other and affect other information [3]. The material previously understood may be important for the next material [4].

As a relentless science, it certainly requires adequate numerical association skills. Numerical relations is a skill that must be created and acquired, because satisfactory numerical association skills will be crucial for students to find relationships of various ideas in arithmetic and apply mathematics in everyday life [5]

The capacity of students to interconnect topics in math and associate the science with regular daily life is very important. Due to its importance, it can help students understanding the ideas that exist in arithmetic [6]. This is supported by the exploration of other studies which reveals that mathematical connection skills are an important part that must be mastered by students at every level of teaching [7] In addition, another exploration revealed that numerical connections can increase students' thinking capacity and capacity to associate concepts both inside and outside numerical ideas [8] .

Mathematical Connection is the compatibility between mathematical topics, progress between mathematics and different disciplines, and coherence with current reality or in ordinary daily life [9] . Numerical connection is the ability to associate mathematics within itself, mathematics 
with different sciences, and arithmetic with ordinary everyday life [10] . Another opinion about mathematical connections is the ability to relate calculated and procedural information by utilizing numerical ideas in other fields and ideas in regular daily life [11].

External mathematical connection is a person's ability to find the use of numerical ideas to deal with problems in everyday life [12]. Meanwhile mathematical connection is the ability of students to connect numerical ideas either between subjects in arithmetic or between numerical ideas and ideas in different fields [3]. In light of this statement, the researcher captures those mathematical connections are relationships or correspondences between points in mathematics, between science and different fields, and between numerical ideas and ordinary life.

The markers used by analysts on numerical association capacity includes (1) Understanding numerical ideas, (2) Applying numerical ideas to solve issues appropriately. (3) Applying numerical ideas from other numerical points to handle the issues, (4) clarifying articles with numerical ideas, and (5) Utilizing numerical ideas on issues identified with everyday life appropriately.

Mathematical connections can be formed according to concepts if students initially understand the ideas they are learning about [13]. Each student has a different learning style in understanding ideas in science [14]. David Kolb organizes student learning styles into four: (1) Converger, people are attracted to look for the use of grounded hypotheses. This style is a mixture of Abstract Conceptualization and Active Experimentation. (2) Accommodator, people that focus on test discovery. This style is a combination of Concrete Experience and Active Experimentation. (3) Diverger, people see miracles from different perspectives. This style is a combination of Concrete Experience and Reflective Observation, and (4) Assimilator, people understand the problem thoroughly and then solve it. This style is a combination of Reflective Observation and Abstract Conceptualization [15]. The learning style diagram can be seen in Figure 1.

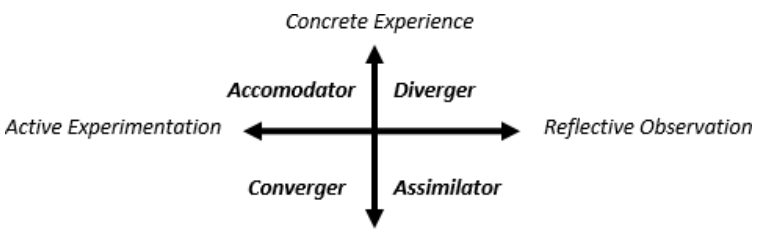

Abstract Conceptualization

Figure 1 Kolb diagram [16]
Given the four classifications of learning styles as pointed out by David Kolb, scientists are interested in finding out a profile of the mathematical connections of high school students viewed from accommodator and diverger learning styles. The accommodator and diverger learning styles both use active experience to capture the information. Students with divergentlearning styles process the information obtained by observing perspectives from various points of view. Meanwhile, the accommodator proves the information by doing it directly. Hence, this research was conducted at the junior high school level which occupies a moderate achievement position in the National Examination in Karanganyar Regency, namely Kebakkramat State High School.

The results of the National Examination by the Department of Education and Culture show that the absorption of trigonometry and geometry subjects has the lowest level among other materials in mathematics. Trigonometry and geometry materials can only be handled accurately by $34.63 \%$, this number is the most minimum number compared to other materials. Based on this data, in this research the geometry material was chosen to measure students' mathematical connections. This exploration has novelty from otherson studying students' thinking styles with students' mathematical connections [17]. Another researcher examined the profile of mathematical connections as far as the level of scientific ability [18]. Meanwhile, in this study, the author raised the novelty of students' mathematical connections when viewed from each learning style according to David Kolb.

This study was also used as a source of perspective for the thesis "Analysis skills of students' mathematical connection based on the learning style of David Kolb, students grade XI at SMA Negeri Kebakkramat".

\section{RESEARCH METHODS}

This research is a descriptive- exploratory study with a qualitative approach that reveals the importance of themeaning behind the miracles that occur. The subjects in this study were students of class XI SMAN Kebakkramat Karanganyar Regency. Subjects weretaken through purposive examination and then snowball sampling. Subjects were selected randomly and subject sampling was stopped when the data was completed. The information selection procedure that has been used is a mathematical connection test adjusted to the indicator of mathematical connection ability. 
Questions and answers withsubjects and tests rely on analysis of mathematical connections.

Students are given assignments to complete and these tasks will be assessed, also questions and answers are carried out with students to find out in depth about the system of consideration that is being done by students in dealing with problems. Then the researcher took the next subject with the same learning style and same treatment. The results obtained from the second subject are then triangulated with the first subject, if there is no difference between them, the examination is stopped on the second subject.

The test instruments and interview guidelines were validated by 2 UMSlecturers, 2 UNS lecturers, and 1 mathematics teacher at SMAN Kebakkramat. Meanwhile, the questionnaire statement was validated by three psychology lecturers at UMS. The triangulation used in this examination is technical triangulation. The survey was used to select students with accommodator and diverger learning styles. To obtain student learning styles, students were given a David Kolb learning style questionnaire consisting of four answer choices, namely very appropriate, appropriate, not suitable, veryinappropriate. By calculating the answerscores on the learning style questionnaire, the highest score determines the students into the appropriate learning style. Therefore, students are divided into each of their learning styles.

\section{RESEARCH RESULTS AND DISCUSSION}

\subsection{Results}

Students' mathematical connectionsare viewed from the mathematical connections written test. It is in the form of two questions that are tailored to the mathematical connection indicator. The test is given to students who have accommodator and converger learning styles to analyze their mathematical connection abilities. Learning style groupings were obtained from the David Kolb learning style questionnaire which was given to 36 students. Questionnaires were given to 36 students to group students into converger, accommodator, diverger, and assimilator learning styles.

The questionnaire results show student that has Converge learning styles is 10 students, students that has accommodator learning styles is 10 students, students with diverger learning styles are 10 students, and 6 students with assimilator learning style. This shows the heterogeneity of each student's learning style which affects students' connection abilities. Presentation of learning style grouping results can be seen in the following diagram on Figure 2.
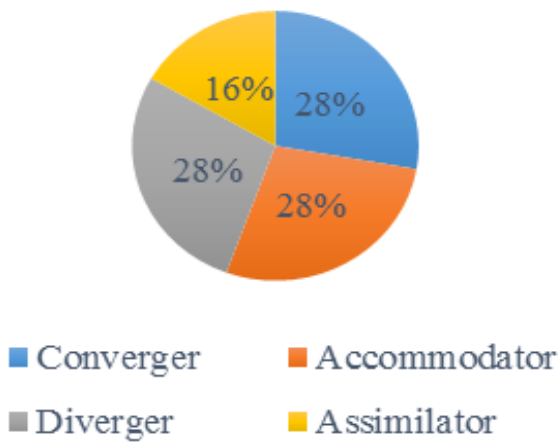

Figure 2 Presentation of learning style David Kolb

Based on the Figure 2 above the first subject is taken. Students with accommodator and diverger learning stylesare given the same form of tests and interviews. Subjects were taken randomly and stopped when the researcher did not find anything new from the previoussubject. This study involved 2 subjects with accommodator learning styles and 2 subjects with divergent learning styles. The following are the results of the writtentests and interviews conducted with each subject.

\subsubsection{Accommodator subject analysis}

\subsubsection{Written test First subject number 1}

The result of the first subject's written test with an accommodator learning style.

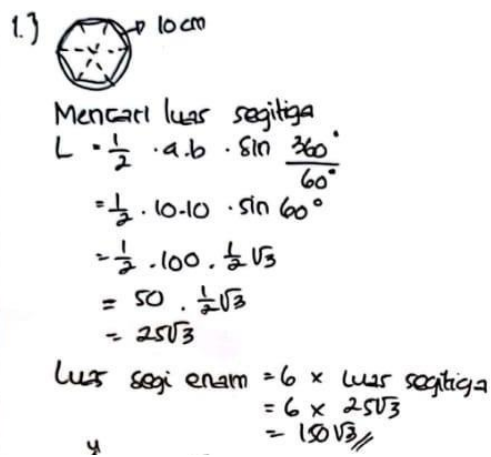

Figure 3 Answers of Accommodator Student number 1

Based on Figure 3 the subject wrote the answer with illustrations of circles and hexagons. S-Ac1 writes the information in the form of the image to represent what is known from the problem. Students use the properties of the circle material to represent problems. S-Ac1 uses the formula for the area of a triangle with an angle of 60 degrees to find the area 
of a triangle, where 60 degrees is obtained from $360 / 6$. Then multiply by 6 according to the number of triangles. Based on Figure 3 S-Ac1 makes a representation of the results obtained from the problem.

The First Subject Interview Transcript number one

Q : What do you know after reading this question?

$\mathrm{S}$-Ac1 : in the problem it is known thatthere is a regular hexagon with a $10 \mathrm{~cm}$ outer circle radius, then we were asked to find the area of the hexagon.

Q : From the picture, which part is the radius of the outer circle?

S-Ac1 : This is it.

Q : Is there any other information that you get from the question?

S-Ac1 : No, there is no other information.

$\mathrm{Q} \quad$ : how long is the radius inside?

S-Ac1 : It's 10.

$\mathrm{Q} \quad$ : where did you get the number of 10?

$\mathrm{S}-\mathrm{Ac1}$ : from the outer radius, sis.

Q : are the outer and inner radius the same?

S-Ac1 : Yes, Sis. because the hexagon is formed with the same triangle

Q : ok, then how do you solve this problem?

S-Ac1 : using the formula for the area of a triangle, where the angle is

60 degrees. Then I find the area of the hexagon by multiplying the area of the triangle by 6.

$\mathrm{Q} \quad:$ why is it multiplied by 6?

S-Ac1 : because there are 6 trianglessis

Q : good. Are you sure you'reright with your answer?

S-Ac1 : sure sis.

Based on the results of the written test and interview with the first subject for question number 1 , it was found that the subject was able to write and explain information obtained from other math topics in clear and easy-to-understand sentences. Subjects was also able to write and explain solutions using concepts in trigonometry material in clear and easy to understand sentences. Subject was able to write and to explain clearly the concepts and the procedures in solving problems.

\subsubsection{Written test first subject number 2}

Based on Picture 2 the subject writes the answers with illustrations of triangles. S-Ac1 writes what is known to be the lengths of sides $\mathrm{AB}$ and $\mathrm{AC}$. The subject writes that the measure of angle $\mathrm{A}$ is 120 degrees. S-Ac1 writes the solution by determining one lengths of the sides of the triangle illustrated by the cosine rule.

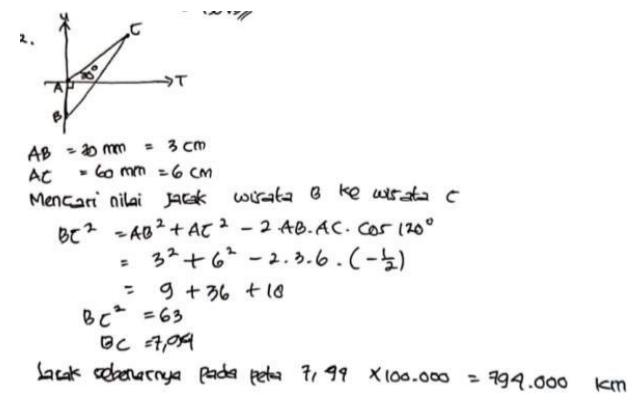

Figure 4 Answers of Accommodator Student number 2

The first subject Interview Transcript number two

Q : what do you know afterreading the question?

S-Ac1 : a path that forms a trianglewith a path length from A to $C 60 \mathrm{~mm}$ and A to $B 30 \mathrm{~mm}$.

Q : good. Is this information sufficient to solve theproblem?

S-Ac1 : Yes, it is.

Q : What steps did you take to solve the problem?

$\mathrm{S}-\mathrm{Ac1}$ : I use the cosine rule formula to find the length ofthe path $B$ to $C$ sis

Q : ok. Are there any problems while working?

S-Ac1 : No Sis

Q : are you sure about your answer?

S-Ac1 : Yes, I am.

Q : ok, here you are multiplying the results of the previous path by 100,000, should it be multiplied like that?

S-Ac1 : Yes, Sis. Because the questionis asked to determine the actual distance sis.

Based on the results of the written test (Figure 4) and interview with the first and second subjects, there were no significant differences in completion and interview results. Both subjects can meet the five indicators of mathematical connection. The subject is able to solve the problem correctly. Subjects are also able to explain in detail the steps and connections betweenconcepts.

The second subject with the Accommodator learning style also met five indicators. The results of 
the written test and interview on the second subject did not have a significant difference with the first subject. Therefore, the mathematical connection on the subject of the Accommodator learning style fulfills the five indicators of the mathematical connection.

\subsubsection{Analysis of Subject Diverger}

\subsubsection{The written test of the first subject number 1}

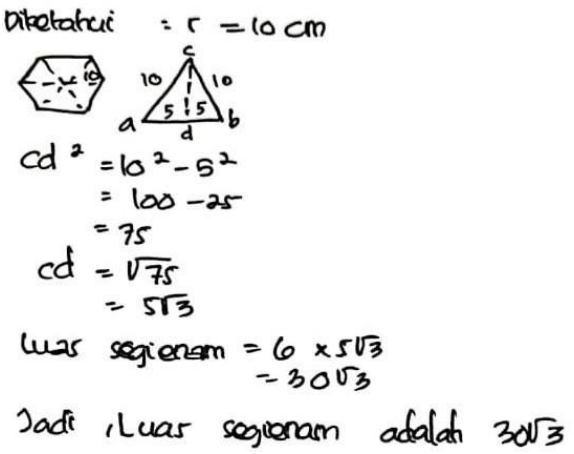

Figure 5 Answers of Diverger Students number 1

Based on Figure 5, the subject writes answers with illustrations of hexagons and triangles that have a high line with a side length of 10 each. S-D1 writes information in the form of the image to represent what is known from the problem. Students use the properties of the circle material to represent problems. S-D1 uses the Pythagorean formula to find the height of the triangle. The subject multiplies the height of the triangle by 6 to find the area of the hexagon.

The First Subject Interview Transcript number 1

Q : Good. What did you get after reading the question?

$\mathrm{S}-\mathrm{D} 1 \quad$ : in the problem it is knownthat there is a regular hexagon with an outer circle radius of $10 \mathrm{~cm}$, then we're asked to find the area of the hexagon.

Q : From your drawing, which part that shows the radius of the outer circle?

S-D1 : The sides of this hexagon, Sis.

$\mathrm{Q}$ : In your answer, you describe a picture of an equilateral triangle, where did the triangle come from?

S-D1 : It comes from the hexagon, Sis. There are six triangles in this hexagon. Then I separated the triangle beside it.

Q : ok, then how do you solve this problem?
S-D1 : From the triangle image, I found the height using Pythagoras. Then I multiply it by 6 sis.

Q : why is the height multiplied by 6 ?

S-D1 : because of the hexagon, then there are 6 triangles.

Q : Are we looking for the height?

S-D1 : No, Sis, the extent of the area. Oh yes, it turned out to bewrong, sis, I should have looked for the extent of the area first and then multiplied it by 6 sis.

Q : good. Any other corrections from your answer?

S-D1 : no, sis.

Q : Is there no other concept that can be used to solve this problem? For example in thematerial trigonometry itself.

S-D1 : No sis

Based on the results of written tests and interviews, the diverger subject was able to write and explain the information obtained from other math topics in clear and easy-to-understand way. Subjects are unable to write and explain solutions using concepts in trigonometry material in clear and easyto-understand way. Subjects are able to write and explain concepts and procedures in solving problems clearly.

\subsubsection{First subject written test number 2}
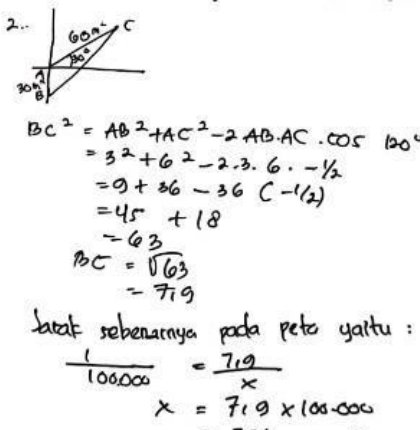

Figure 6 Student answers Diverger number 2

Subject writes answers with illustrations of triangles. S-D1 writes what is known to be the lengths of sides AB and AC. S-D1 writes the solution by determining the length of one of the sides of the triangle illustrated by the cosine rule.

The First Subject Interview Transcript number 2

Q : Before proceeding to the next question, please read and pay close attention to question number 2.

S-D1 : On a map with a scale of 1: 100.000, 
the location of tourist attractions $C$ from tourist attractions $A$ is $30^{\circ}$, wheretourist attractions $C$ is located at the northeast direction of tourist attractions $A$. If the measurement results on the map are obtainedthe distance from tourist spot $A$ to tourist spot $C$ is $60 \mathrm{~mm}$ and the distance from touristspot $A$ to tourist spot $B$ is $30 \mathrm{~mm}$, with tourist spot B is located in the south of tourist spot A. Determine the actual distance from tourist spot B to tourist spot $C$ !

$\mathrm{Q}$ : What do you know after reading the question?

S-D1 : the distance between tourist $A$ and $B$ is $30 \mathrm{~mm}$, A to $C$ is $60 \mathrm{~mm}$ and the angle formed between $A$ and $C$ is $30^{\circ}$.

$\mathrm{Q} \quad$ : is that all?

S-D1 : Yes, Sis.

Q : Are you sure about the answer?

S-D1 : Yes, I am, Sis

Q : What steps did you take to solve the problem?

S-D1 : I used the cosine rule formula, Sis $\mathrm{Q} \quad$ : what is the cosine rule determine? S-D1 : Length of BC Sis

$\mathrm{Q} \quad$ : why is the value of $A B$ is 3 even though in the beginning you wrote that, based on what you know $A B=30 \mathrm{~mm}$ ?

S-D1 : I changed everything to $\mathrm{cm}$. Sis

Q : Okay. How do you get the actual distance on the map?

S-D1 : I compare it according to the comparison on yourquestion.

Q : good. Are there any additional corrections to the answer that you wrote?

S-D1 : no, that's enough

Based on the results of the written test (Figure 6 ) and interview of the two diverger subjects, it was found that the subjects were not ableto write the solution using the concepts in the trigonometric material correctly. The diverger subjects cannot fulfill indicator number 2 on the mathematical connection test. The subject solves the problem using the Pythagorean concept and does not know the concepts contained in the trigonometry material. Students with divergent learning styles are only able to fulfill 4 indicators of mathematical connection.

The second subject with Diverger learning style also fulfills four indicators. The results of the written test and interview on the second subject did not have a significant difference with the first subject. Therefore, the mathematical connection on the subject of Diverger learning styles fulfills four indicators of mathematical connection.

\subsection{Discussion}

Based on the results of tests and interviews, students with the accommodator learning style are able to solve problems both in writing and orally. The accommodator subjectis able to write down the information obtained from other mathematical topics correctly and is able to explain it. The application of the trigonometry concept is carried out by the subject appropriately. The subject is also able to explain the completion procedure appropriately. In addition, the subject is also able to apply mathematical concepts related to other fields and related to everyday life. This is in line with previous research which explains that learning styles affect students' mathematical ability, it is necessary to make efforts to improve and develop, from the perspective of knowledge, understanding, learning methods, and skills of the students [19]. Based on the results of the analysis, it can be concluded that students with the accommodator learning style have a high mathematical connection.

The first and second subjects in the divergent learning style are able to write and explain what is known in the problem, which is the outer radius of the circle onthe hexagon. Subjects are able to apply concepts outside of trigonometry appropriately. However, the subject was unable to write and explain the solution using the concepts in the trigonometric material correctly. The subject made an error in the selection of steps, and did not know the concepts in trigonometry. Both subjects are also able to write and explain concepts and procedures in solving problems clearly. In addition, the subject is able to write and explain the information obtained from problems related to everyday life appropriately. The subject is able to divide and solve the second problem correctly. In the fifth indicator where the students can write and explain the information obtained from problems related to everyday life appropriately, the subject is able to divide and solve the second problem correctly.

\section{CONCLUSION}

High school students in XI grade with an accommodator learning style have a mathematical connection that is superior to students with a 
diverger learning style. Based on the results of the analysis, students with the accommodator learning style were able to fulfill five indicators of mathematical connection. Meanwhile,students with divergent learning styles are able to fulfill only 4 indicators of mathematical connection, the indicator thatcannot be fulfilled is the indicator number 2 . The five indicators that have been mentioned are first to apply mathematical concepts from other math topics to solve problems. Second, to apply concepts in trigonometry material to solve problems correctly. The third is to represent concepts and procedures. Fourth, to apply mathematical concepts to problems related to everyday life. Fifth, to use mathematicalconcepts on questions related to other subjects.

\section{REFERENCES}

[1] S. W. P. Nugroho, Riyadi, Triyanto, And S. W. P. Nugroho, "The Analysis Of Algebra Creative Thinking Skill Based On Strong Mathematical Habit Of Mind," J. Phys. Conf. Ser., Vol. 1538, No. 1, 2020, Doi: 10.1088/1742-6596/1538/1/012100.

[2] Y. Permana And U. Sumarmo, "Mengembangkan Kemampuan Penalaran Dan Koneksi Matematik Siswa Sma Melalui Pembelajaran Berbasis Masalah," Educationist, Vol. I, No. 2, Pp. 116-123, 2007.

[3] Ruspiani, "Kemampuan Siswa Dalam Melakukan Koneksi Matematika," Tesis. Sps Upi Bandung, No. December, 2000, [Online]. Available:

Http://Linkinghub.Elsevier.Com/Retrieve/Pii/ S1877042814012348.

[4] E. D. P. Latipah And E. A. Afriansyah, "Analisis Kemampuan Koneksi Matematis Siswa Menggunakan Pendekatan Pembelajaran Ctl Dan Rme," Matematika, Vol. 17, No. 1, Pp. 1-12, 2018, Doi: 10.29313/Jmtm.V17i1.3691.

[5] M. D. Siagian, "Kemampuan Koneksi Matematik Dalam Pembelajaran Matematika," Mes J. Math. Educ. Sci., Vol. 1, No. 2, Pp. 5867, 2016.

[6] A. F. Ni'mah, S. Setiawani, And E. Oktavianingtyas, "Analisis Kemampuan Koneksi Matematika Siswa Kelas Ix A Mts Negeri 1 Jember Subpokok Bahasan Kubus Dan Balok," J. Edukasi, Vol. 4, No. 1, P. 30, 2017, Doi: 10.19184/Jukasi.V4i1.5087.
[7] R. Siregar And M. D. Siagian, "Mathematical Connection Ability: Teacher's Perception And Experience In Learning," J. Phys. Conf. Ser., Vol. 1315, No. 1, 2019, Doi: 10.1088/1742$6596 / 1315 / 1 / 012041$

[8] A. K. Kenedi, I. K. Sari, S. Ahmad, Y. Ningsih, And M. Zainil, "Mathematical Connection Ability Of Elementary School Student In Number Materials," J. Phys. Conf. Ser., Vol. 1321, No. 2, 2019, Doi: 10.1088/1742$6596 / 1321 / 2 / 022130$

[9] M. S. Noto, W. Hartono, And D. Sundawan, "Analysis Of Students Mathematical Representation And Connection On Analytical Geometry Subject," Infin. J., Vol. 5, No. 2, P. 99, 2016, Doi: 10.22460/Infinity.V5i2.216.

[10] P. N. Malasari, H. Nindiasari, And Jaenudin, "A Development Of Mathematical Connecting Ability Of Students In Junior High School Through A Problem-Based Learning With Course Review Horay Method," J. Phys. Conf. Ser., Vol. 755, No. 1, 2017, Doi: 10.1088/17426596/755/1/011001.

[11] K. Mandur Et Al., "Kontribusi Kemampuan Koneksi, Kemampuan Representasi, Dan Disposisi Matematis Terhadap Prestasi Belajar Matematika Siswa Sma Swasta Di Kabupaten Manggarai," 2016.

[12] D. A. Kusuma, D. Suryadi, and J. A. Dahlan, "Improving external mathematical connections and students' activity using ethnomathematics," J. Phys. Conf. Ser., vol. 1157, no. 3, 2019, doi: 10.1088/1742$6596 / 1157 / 3 / 032120$

[13] Mulyono and R. Hadiyanti, "Analysis of mathematical problem-solving ability based on metacognition on problem-based learning," $J$. Phys. Conf. Ser., vol. 983, no. 1, 2018, doi: 10.1088/1742-6596/983/1/012157.

[14] M. Romli, "Profil Koneksi Matematis Siswa Perempuan Sma Dengan Kemampuan Matematika Tinggi Dalam Menyelesaikan Masalah Matematika," JIPMat, vol. 1, no. 2, pp. 145-157, 2017, doi: 10.26877/jipmat.v1i2.1241

[15] Zulfiani, I. P. Suwarna, and M. F. Sumantri, "Science adaptive assessment tool: Kolb's learning style profile and student's higher order thinking skill level," J. Pendidik. IPA Indones., 
vol. 9, no. 2, pp. 194-207, 2020, doi: 10.15294/jpii.v9i2.23840.

[16] A. Y. Kolb and D. A. Kolb, "The Kolb Learning Style Inventory - Technical Specifi cations," no. January 2005, 2015.

[17] I. S. Muflihah, N. Ratnaningsih, and V. Apiati, "Analisis Kemampuan Koneksi Matematis Ditinjau Dari Gaya Berpikir Peserta Didik," J. Authentic Res. Math. Educ., vol. 1, no. 1, pp. 68-77, 2019.

[18] S. Suhandri, H. Nufus, and E. Nurdin, "Profil Kemampuan Koneksi Matematis Mahasiswa dalam Menyelesaikan Masalah Matematika Berdasarkan Level Kemampuan Akademik," J. Anal., vol. 3, no. 2, p. 115, 2017, doi: 10.15575/ja.v3i2.1919.

[19] G. Dwirahayu, D. Kustiawati, and I. Bidari, "Corresponding Habits of Mind and Mathematical Ability," J. Phys. Conf. Ser., vol. 895 , no. 1, 2017, doi: 10.1088/1742$6596 / 895 / 1 / 012013$. 